\title{
Development and Evaluation of Inclined Plate Metering Mechanism for Radish (Raphanus sativus) Pelleted Seeds
}

\author{
Anand Gautam*, Rohinish Khurana, Gursahib Singh Manes, \\ Anoop Dixit and Aseem Verma
}

\author{
Department of Farm Machinery and Power Engineering, COAE\&T, PAU, \\ Ludhiana 141004, Punjab, India \\ *Corresponding author
}

\section{A B S T R A C T}

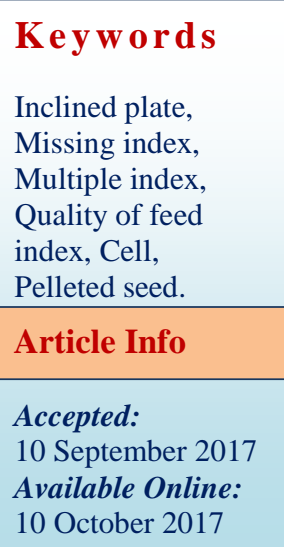

\section{Keywords}

Inclined plate, Missing index Multiple index, 10 October 2017
The ability to place seeds at a given distance apart in a row is an important performance factor of a planter with single seed metering mechanism. Inclined plate seed metering device was developed and evaluated in laboratory for singulation and uniform placement of radish seeds with different pelleting ratio viz. 1:1, 1:2 and 1:3 pelleted. Metering device was tested at three inclinations of $40^{\circ}, 45^{\circ}$ and $50^{\circ}$ using plates having three different groove number 18, 24 and 30 on cells. Average seed spacing obtained at in $S_{3}$ seed, $\theta_{2}$ angle in forward speed $2.0 \mathrm{~km} / \mathrm{h}$, the average spacing was observed to be $5.72,5.66$ and $5.61 \mathrm{~cm}$ for 18, 24 and 30 groove plate respectively. Missing index at $2.0 \mathrm{~km} / \mathrm{h}$ forward speed with 24 groove seed metering plate with $45^{\circ}$ inclination angle was $13.0 \%$ and multiple index was $12.0 \%$. The overall quality of feed index obtained with these parameters was $75.0 \%$ which is maximum when compared with other seed treatments, forward speeds and types of seed metering plate combinations with different angle of inclination of plates. The selection of plate inclination and type of metering cell for the planter was purely based on average spacing, missing index, multiple index and quality of feed index. With 24 groove seed metering plate with $45^{\circ}$ inclination angle and forward speed of $2.0 \mathrm{~km} / \mathrm{h}$ was selected for the field evaluation.

\section{Introduction}

Radish (Raphanus sativus) is one of the major vegetable crops grown throughout the country. It is widely grown in different parts of the country mainly by small and marginal farmers. In West Bengal and Haryana, this crop has gained the importance crop rather than as a vegetable crop because of its very high export potential. In India, West Bengal is a leading radish growing state followed by Haryana, Assam, Bihar, Odisha, Punjab and Chhatisgarh. The productivity of radish is the highest in Punjab (20.52 t/ha) followed by
Chhatisgarh, Bihar, Haryana and West Bengal (18.3, 15.76, 15.23 and 12.25 t/ha) (Anon., 2015).

In Punjab radish is sown over an area of about 12.33 thousand hectare (2013-14) having production of 253.07 thousand tonne (Anon., 2015). Generally, the radish seeds are sown manually for small scale maintain spacing of 30 to $45 \mathrm{~cm}$ row to row and $7.5 \mathrm{~cm}$ plant to plant for large scale production, broad casting method generally used by the farmers. During 
radish cultivation of seedlings, thinning, weeding and harvesting are the most labour intensive operations. Because of high requirement and shortage of labour, the area under radish cultivation is low and can be increased by mechanization of this crop.

Performance of single seed planter mainly depends on its ability to place seeds at a given distance apart. Under field conditions, it is often impossible to directly measure seed placement. An alternative is to measure the spacing between plants after they emerge. When examining the spacing between the plants once they emerge, considerable variability often exists in the plant-to-plant distance. Much of the variability in spacing could be removed by evaluating planters under laboratory conditions. However, field trails are also needed to accurately evaluate how planters perform in field. The main aim is to quantify the observed variability in a way that will allow one to make meaningful comparisons between single seed metering devices. A number of factors affect the spacing of plants. The seed selection mechanism may fail to select or drop a seed resulting in large spacing between the seeds. The device may pick and drop multiple seeds resulting in small spacing between seeds. Seed tube design and soil conditions along with other factors determine the final placement of seed. As all seeds may not germinate, the distribution of plant spacing will differ from the intended seed spacing.

The most widely used measures tested and compared (Kachman and Smith, 1995) mean, standard deviation, quality of feed index, multiple index, missing index and precision. These measures were based on the theoretical spacing (X ref), specified in ISO 7256-1 standard (Anon., 1984), and gave a good indication of spacing distribution. Concluded that the mean and the standard deviation of seed spacing did not offer an appropriate evaluation of planter performance on seed distribution (Kachman and Smith, 1995). The final selection of metering device also depends on multiple index and missing index. Developed two devices for small seed metering based on the picking action with pincette type picking unit (Shibata et al., 1990). One device was designed with a spring pick up unit and other device with electromagnetic pick-up type. Lower misses were observed for spring pickup type at low peripheral speed of $13.4 \mathrm{~cm} . \mathrm{s}^{-1}$ with $71 \%$ seeding efficiency. In case of electromagnetic pickup device, no misses were observed even at high peripheral speeds with $80 \%$ seeding efficiency. Designed a special- shaped spiral groove precision seed metering device for small grain crops (Zang and Guo, 2009). The spiral groove sections with rectangular bottom, V-shaped bottom and U-shaped bottom were used for seed metering. Vshaped bottom was chosen, because of its stability for seeding. Development of manually operated electrostatic planter for small seed was reported (Ahmed and Gupta, 1994).There was no damage to seeds passing through metering device, but number of seeds picked up by electrostatic charge varied from 2-6 seed per hill. Study on feasibility of precision planting by cell type metering device for radish seed was reported (Otsuka $e t$ al., 1986). Kowalczuk and Zarajczyk (2006) examined the quality of carrot sowing with belt type seeder at 3 working speeds of 0.7 , 1.0 and $1.4 \mathrm{~m} . \mathrm{s}^{-1}$, and found the best working speed as $0.7 \mathrm{~m} . \mathrm{s}^{-1}$. Based on the results of the laboratory evaluation, 30 groove seed metering plate and a forward speed of 1.5 $\mathrm{km} / \mathrm{h}$ was selected for the field evaluation for tractor operated inclined plate metering device for onion seed planting (Grewal et al., 2015). A large number of planter designs are available for bolder seeds, but very little information is available on small seed like onion, carrot, radish particularly under Indian situations. Hence, the present study was 
conducted with the objective to design the metering mechanism for small sized seed like radish and evaluate it for uniformity of seed placement.

\section{Materials and Methods}

\section{Metering system}

Mechanical seed metering devices in planter usually have cells on a moving member to have positive seed metering. Commonly recommended metering systems on planters are horizontal plate, inclined plate, vertical rollers with cells, and cups over the periphery (Anon., 1991). Since radish seeds are small in size and very susceptible to mechanical damages, metering with vertical and horizontal plate metering mechanism were not considered. Laboratory experiment was thus conducted with inclined plate cell type metering mechanism having different cell numbers (Figure 1). The types of radish seeds used for the study are shown in Figure 3.

The average values for roundness value of radish seed were $0.79,0.82$ and 0.93 for $1: 1$, $1: 2$ and 1:3 pelleted seed respectively, Table 1.This gave clue to use slant shape of cells over plate periphery. The values of angle of repose for 1:1 pelleted $\left(S_{1}\right)$, 1:2 pelleted $\left(S_{2}\right)$ and 1:3 pelleted $\left(\mathrm{S}_{3}\right)$ seeds were $25.09^{\circ}$, $23.70^{\circ}$, and $23.16^{\circ}$ respectively (Table 1 and Fig. 2).

The hopper slope was thus decided at $45^{\circ}$ by the values of angle of repose of the seeds.

\section{Laboratory test}

The performance of cells of different shapes was evaluated using a sticky belt and by varying inclination of the metering device for both coated and uncoated seeds (Table 2). The sticky belt mechanism consisted of $4 \mathrm{~m}$ long endless canvass belt mounted on two endless rollers spaced $100 \mathrm{~cm}$ apart along with a seed hopper and power transmission unit of belt pulley system with reduction gear and driving roller driven by a $4 \mathrm{~kW}$ motor. Observations were taken on the spacing between two adjacent seeds over the greased belt. Based upon the in-between spacing of 50 seeds, five measures of performance parameters viz. average spacing, multiple index, missing index, quality of feed index and precision were determined (Kachman and Smith, 1995).

\section{Performance parameters}

\section{Multiple index}

Multiple index (D) is an indicator of more than one seed dropped within a desired spacing. It is the percentage of spacing's that are less than or equal to half of the theoretical spacing:

$\mathrm{D}=\mathrm{n} 1 / \mathrm{N}$

Where,

$\mathrm{N}=$ Total number of observations, and

$\mathrm{n} 1=$ Number of spacing's in the region less than or equal to 0.5 times of the theoretical spacing.

\section{Quality of feed index}

Quality of feed index (A) is the measure of how often the seed spacing's were close to the theoretical spacing (Kachman and Smith, 1995). It is the percentage of spacing's that are more than half, but not more than 1.5 times the theoretical spacing. The quality of feed index is mathematically expressed as follows:

$\mathrm{A}=\mathrm{n} 2 / \mathrm{N}$

Where, 
$\mathrm{N}=$ Total number of observations, and $\mathrm{n} 2=$ Number of spacing's between 0.5 times the theoretical spacing and 1.5 times of the theoretical spacing.

\section{Missing index}

Missing index is an indicator of how often a seed skips the desired spacing. It is the percentage of spacing greater than 1.5 times the theoretical spacing, and expressed as:

$\mathrm{M}=\mathrm{n} 3 / \mathrm{N}$

Where,

$\mathrm{N}=$ Total number of observations, and

$\mathrm{n} 3=$ Number of spacing's in the region $>1.5$ times of the theoretical spacing.

\section{Degree of variation}

Degree of variation (c) is a measure of the variability in spacing after accounting for variability due to both multiples and skips. The degree of the variation is the coefficient of variation of the spacing that are classified as singles.

$C=S / X_{r \theta f}$

Where,

$\mathrm{S}=$ Sample standard deviation of the $\mathrm{n} 3$ observation,

$\mathrm{X}$ ref $=$ Theoretical spacing

\section{Results and Discussion}

\section{Average spacing}

The average spacing was significantly influenced by all combinations of design variables of the study at 5\% level of significance. Inclination of metering device influenced the average spacing, followed by cell number as indicated by the F-values (Table 3). The average spacing increase with the increase in the ratio of seed treatment at forward speed of $1.0 \mathrm{~km} / \mathrm{h}$, whereas at forward speed of $2.0 \mathrm{~km} / \mathrm{h}$ and $3.0 \mathrm{~km} / \mathrm{h}$ and decrees with number of grooves of the seed metering plate. At $S_{1}$ seed, $\theta_{2}$ angle in forward speed $2.0 \mathrm{~km} / \mathrm{h}$, the average spacing was observed to be $5.18 \mathrm{~cm}, 5.10 \mathrm{~cm}$ and $5.04 \mathrm{~cm}$ for 18, 24 and 30 groove plate respectively.

In $S_{3}$ seed, $\theta_{2}$ angle in forward speed 2.0 $\mathrm{km} / \mathrm{h}$, the average spacing was observed to be $5.72 \mathrm{~cm}, 5.66 \mathrm{~cm}$ and $5.61 \mathrm{~cm}$ for 18,24 and 30 groove plate respectively (Figs. 4-6).

\section{Performance indices}

The distance between plants within a row is influenced by a number of factors including multiple index, missing index, failure of a seed to emerge, and variability around the drop point. Missing, multiple and quality of feed index were highly influenced by all the three design variables at 5\% level of significance.

\section{Multiple index}

Multiple index was influenced by inclination of the metering device, followed by cell shape and type of seed as indicated by the F-values (Table 3). The experimental multiple index for independent parameters are given in Figure 7, 8 and 9. It is apparent that the multiple index was affected by the parameters studied i.e. treatment of seed, inclination angle of planter, forward speed and types of seed metering plate. The average multiple index observed were at $S_{1}$ seed, 24.0, 21.0, 21.0 for 18 groove plate, 24.0, 23.0, 23.0 for 24 groove plate and 27.0, 27.0, 26.0 for 30 groove plate at $\theta_{2}$ angle and forward speed $1.0,2.0,3.0 \mathrm{~km} / \mathrm{h}$ respectively. In $\mathrm{S}_{3}$ seed, $15.0,14.0,12.0$ for 18 groove plate, 18.0, 12.0, 10.0 for 24 groove plate and 20.0, 18.0, 
17.0 for 30 groove plate respectively. Missing index

Missing index was influenced most by plate angle, followed by cell shape, as indicated by the F-values (Table 3). Missing index increased with the increase in forward speed as shown in Figures 10, 11 and 12.

The average missing index observed were at $S_{1}$ seed, 14.0, 14.0, 18.0 for 18 groove plate, $9.0,10.0,15.0$ for 24 groove plate and 12.0, $15.0,17.0$ for 30 groove plate at $\theta_{2}$ angle and forward speed 1.0, 2.0, $3.0 \mathrm{~km} / \mathrm{h}$ respectively. In $\mathrm{S}_{3}$ seed, 15.0, 18.0, 23.0 for 18 groove plate, 13.0, 13.0, 19.0 for 24 groove plate and 13.0, 15.0, 22.0 for 30 groove plate respectively.

\section{Quality of feed index}

Quality of feed index was highly influenced by angle of metering plate, followed by seed and cell shape as indicated by F-values (Table $3)$. The data in Figures 13, 14 and 15 depicts the variation of quality of feed index with respect to the forward speed. The average quality of feed index observed were at $S_{1}$ seed, 62.0, 65.0, 61.0 for 18 groove plate, 67.0, 70.0, 62.0 for 24 groove plate and 58.0, $61.0,57.0$ for 30 groove plate at $\theta_{2}$ angle and forward speed 1.0, 2.0, $3.0 \mathrm{~km} / \mathrm{h}$ respectively. In $S_{3}$ seed, 68.0, 70.0, 65.0 for 18 groove plate, 71.0, 75.0, 69.0 for 24 groove plate and $67.0,67.0,61.0$ for 30 groove plate respectively.

Fig.1 Metering plates used for metering of radish seed
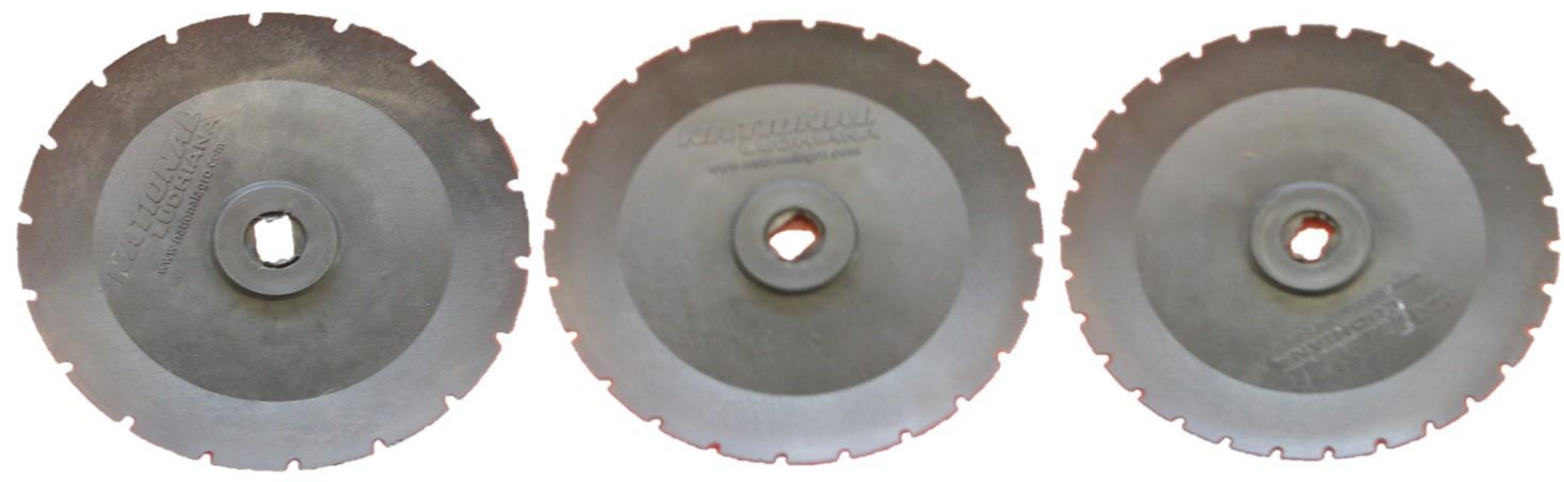

18 Cells 24 Cells 30 Cells

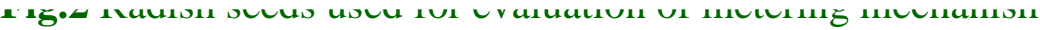

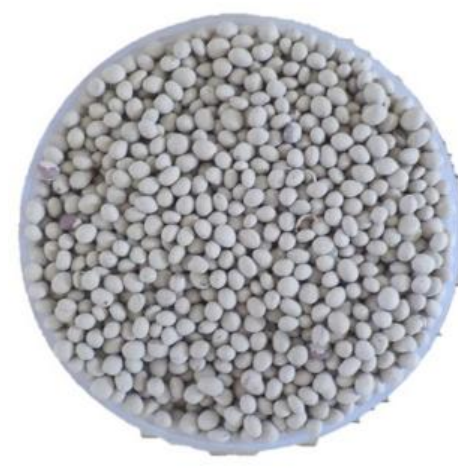

1:1 Pelleted

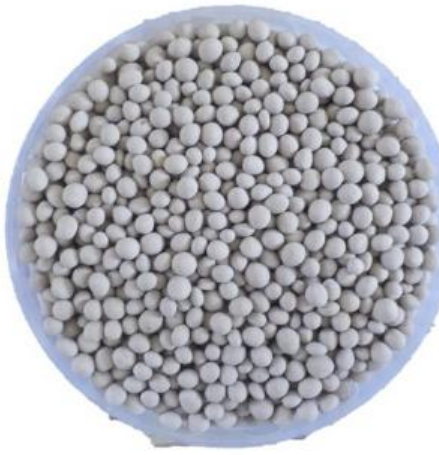

1:2 Pelleted

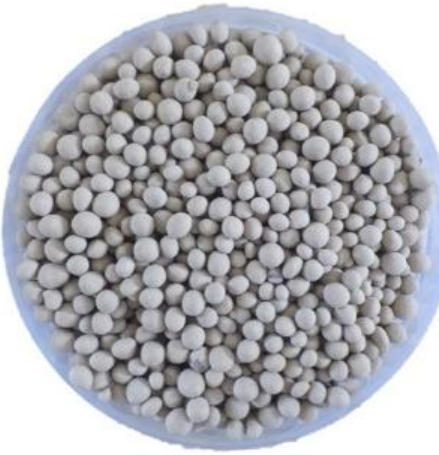

1:3 Pelleted 
Fig.3 Effect of seed treatment, forward speed and type of seed metering plate on radish seeds average spacing at inclination angle of plate $40^{\circ}$

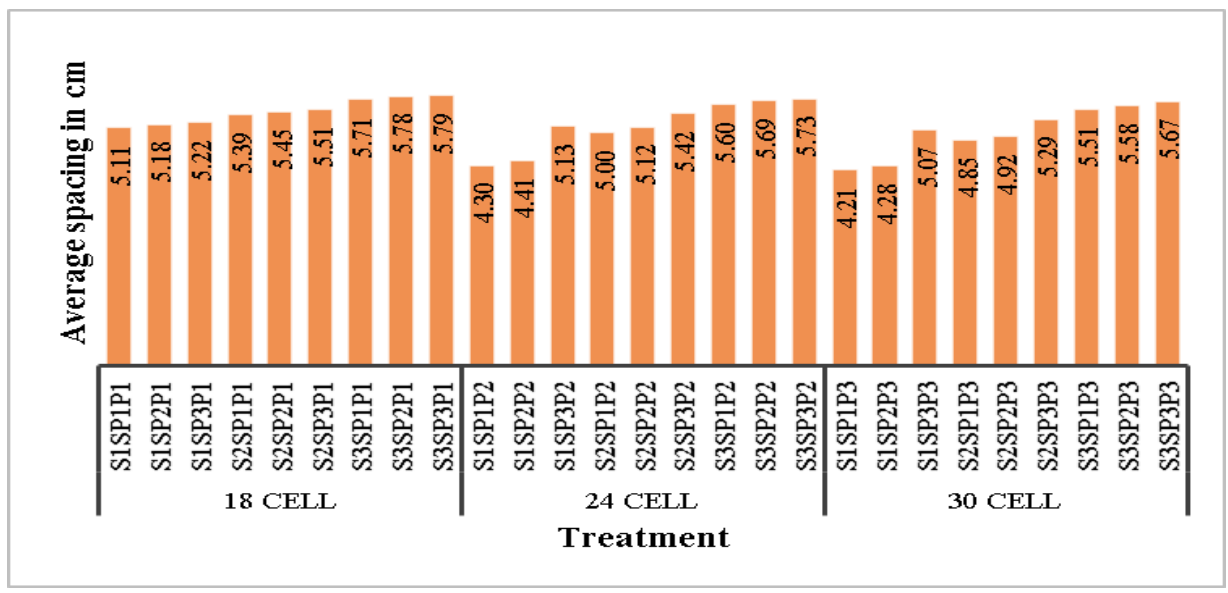

Fig.4 Effect of seed treatment, forward speed and type of seed metering plate on radish seeds average spacing at inclination angle of plate $45^{\circ}$

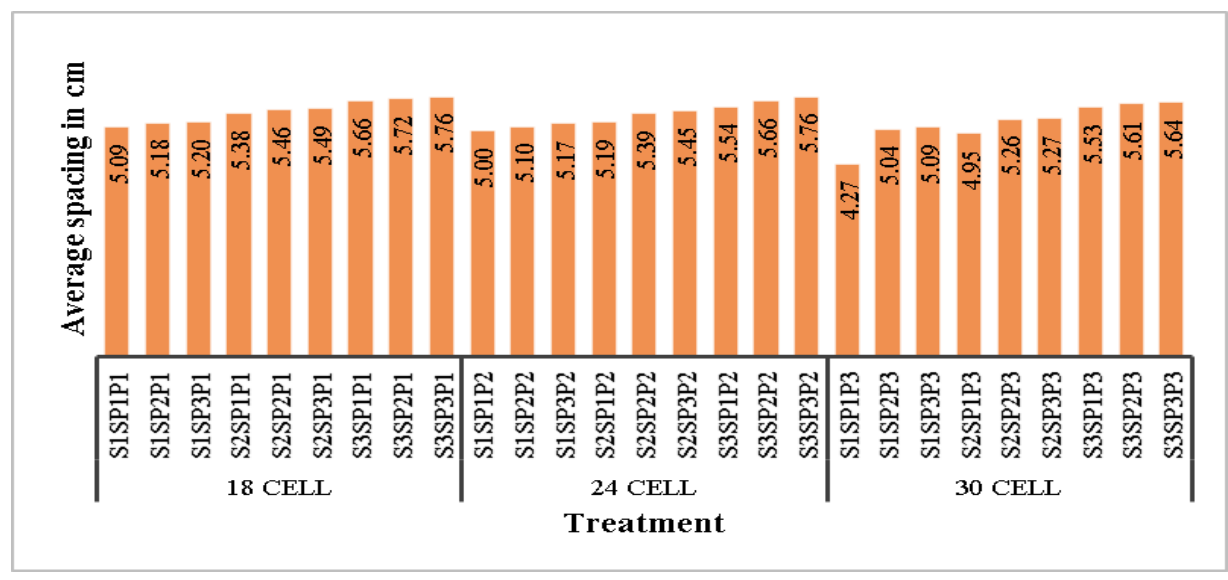

Fig.5 Effect of seed treatment, forward speed and type of seed metering plate on radish seeds average spacing at inclination angle of plate $50^{\circ}$

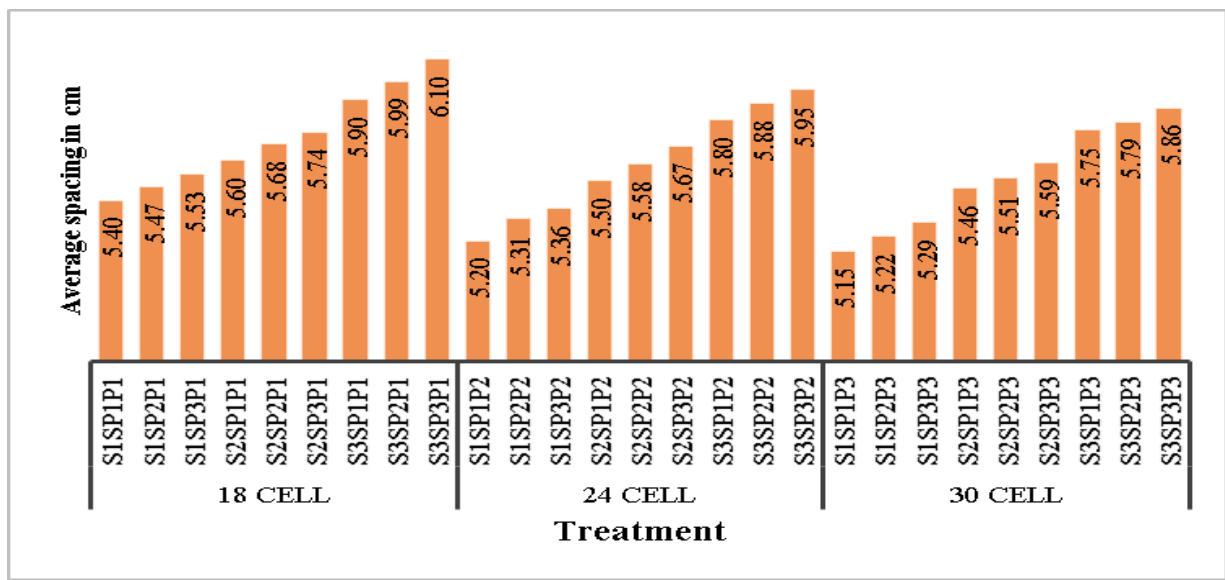


Fig.6 Effect of seed treatment, forward speed and type of seed metering plate on radish seeds performance indices at inclination angle of plate $40^{\circ}$

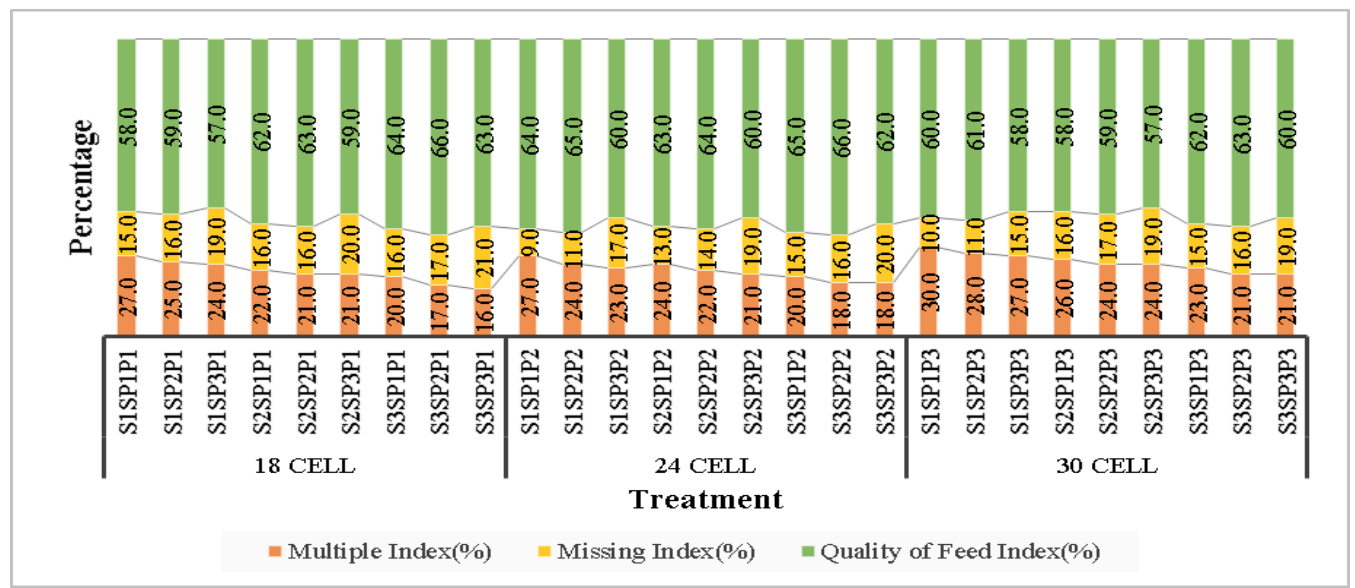

Fig.7 Effect of seed treatment, forward speed and type of seed metering plate on radish seeds performance indices at inclination angle of plate $45^{\circ}$

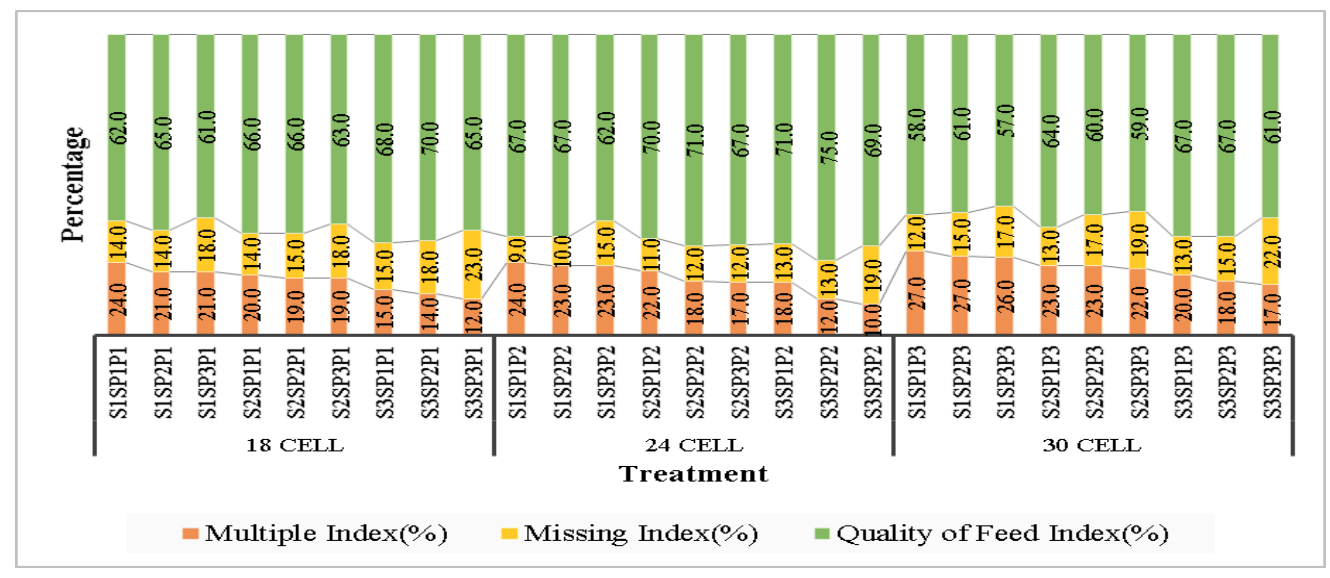

Fig.8 Effect of seed treatment, forward speed and type of seed metering plate on radish seeds performance indices at inclination angle of plate $50^{\circ}$

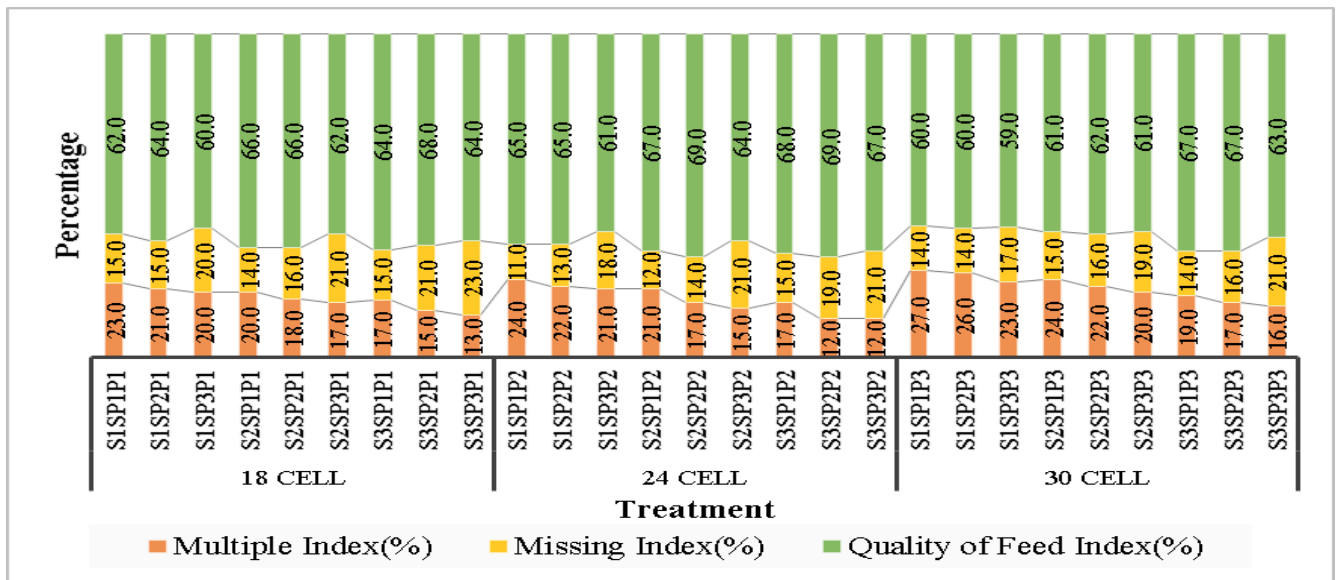


Fig.9 Effect of seed treatment, forward speed and type of seed metering plate on radish seeds degree of variation at inclination angle of plate $40^{\circ}$

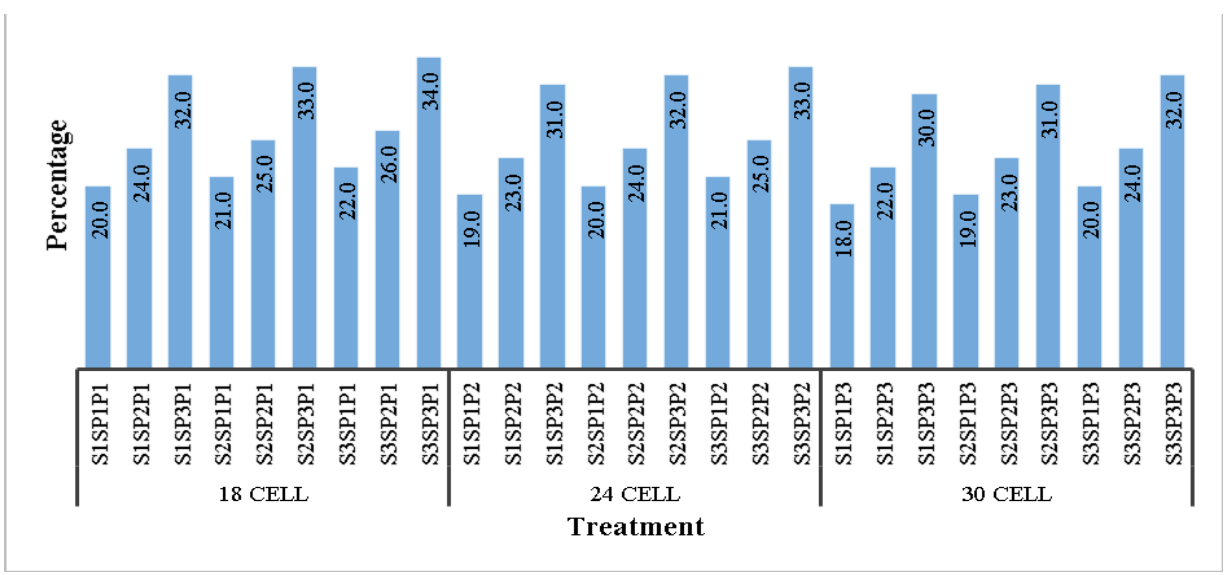

Fig.10 Effect of seed treatment, forward speed and type of seed metering plate on radish seeds degree of variation at inclination angle of plate $45^{\circ}$

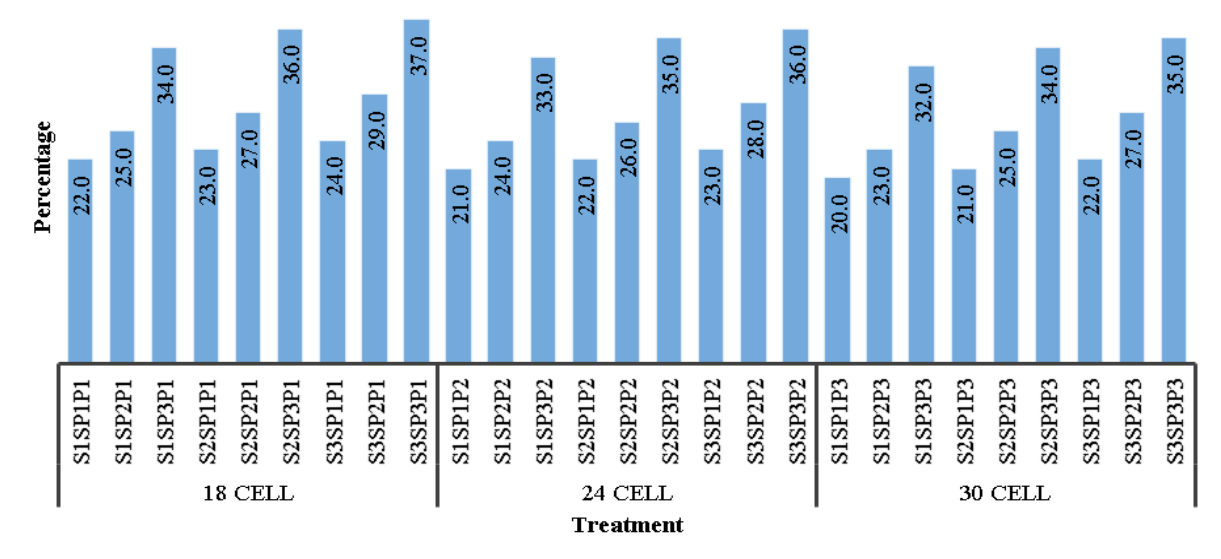

Fig.11 Effect of seed treatment, forward speed and type of seed metering plate on radish seeds degree of variation at inclination angle of plate $50^{\circ}$

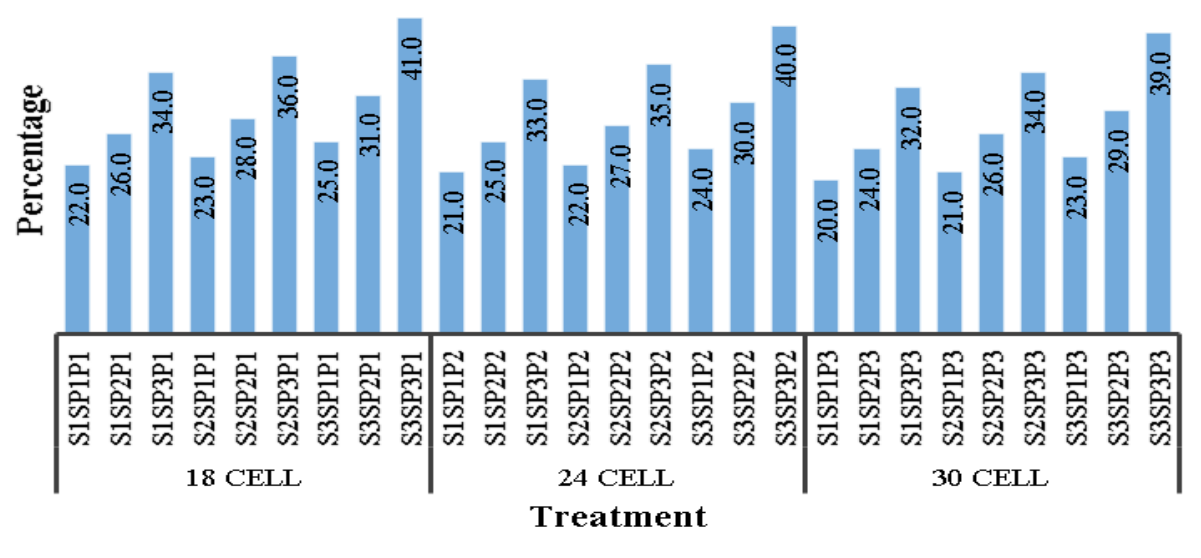


Table.1 Physical and engineering properties of radish seeds under different seed treatments

\begin{tabular}{|l|c|c|c|}
\hline \multirow{2}{*}{\multicolumn{1}{|c|}{ Property }} & \multicolumn{3}{|c|}{ Treatment } \\
\cline { 2 - 4 } & $\mathbf{S}_{\mathbf{1}}$ & $\mathbf{S}_{\mathbf{2}}$ & $\mathbf{S}_{\mathbf{3}}$ \\
\hline Major Dimension & 3.75 & 4.27 & 4.35 \\
\hline Intermediate Dimension & 3.11 & 3.64 & 3.84 \\
\hline Minor Dimension & 2.66 & 3.13 & 3.69 \\
\hline Spherecity value & 0.84 & 0.85 & 0.91 \\
\hline Roundness value & 0.79 & 0.82 & 0.93 \\
\hline Angle of repose (degree) & $25.09^{\circ}$ & $23.70^{\circ}$ & $23.16^{\circ}$ \\
\hline
\end{tabular}

Note: $S_{1}-1: 1$ Pelleted seed; $S_{2^{-}}$1:2 Pelleted seed and S3-1:3 pelleted seed

Table.2 Plan of experiment on metering device

\begin{tabular}{|c|c|c|}
\hline S. No. & System Variable & Level of Variable \\
\hline \multirow{3}{*}{1.} & \multirow{3}{*}{ Seed Treatment $(\mathrm{S})$} & $\mathrm{S}_{1}-1: 1$ Pelleted Seed \\
\hline & & $S_{2}-1: 2$ Pelleted Seed \\
\hline & & $\mathrm{S}_{3^{-}} 1: 3$ Pelleted Seed \\
\hline \multirow{3}{*}{2.} & \multirow{3}{*}{$\begin{array}{l}\text { Inclination of metering } \\
\operatorname{mechanism}(\theta)\end{array}$} & $\theta_{1}-40^{\circ}$ \\
\hline & & $\theta_{2}-45^{\circ}$ \\
\hline & & $\theta_{3^{-}}-50^{\circ}$ \\
\hline \multirow{3}{*}{3.} & \multirow{3}{*}{ Speed of operation $(\mathrm{Sp})$} & $\mathrm{Sp}_{1}-1 \mathrm{kmh}^{-1}$ \\
\hline & & $\mathrm{Sp}_{2}-2 \mathrm{kmh}^{-1}$ \\
\hline & & $\mathrm{Sp}_{3}-3 \mathrm{kmh}^{-1}$ \\
\hline \multirow{3}{*}{4.} & \multirow{3}{*}{ Cell $(\mathrm{P})$} & $\mathrm{P}_{1^{-}} 18$ Number of grooves on Cell \\
\hline & & $\mathrm{P}_{2-}-24$ Number of grooves on Cell \\
\hline & & $\mathrm{P}_{3}-30$ Number of grooves on Cell \\
\hline
\end{tabular}

Table.3 F-values for performance parameters of seed metering mechanism

\begin{tabular}{|l|c|c|c|c|c|}
\hline \multirow{2}{*}{ Source } & \multicolumn{5}{|c|}{ F-Value } \\
\cline { 2 - 5 } & $\begin{array}{c}\text { Average } \\
\text { Spacing }\end{array}$ & Multiple Index & Missing Index & $\begin{array}{c}\text { Quality of Feed } \\
\text { Index }\end{array}$ & $\begin{array}{c}\text { Degree of } \\
\text { Variation }\end{array}$ \\
\hline $\mathbf{S}$ & 706.697 & 972.944 & 170.291 & 166.404 & 113.324 \\
\hline $\boldsymbol{\theta}$ & 223.583 & 35.385 & 387.097 & 120.467 & 135.912 \\
\hline $\mathbf{S p}$ & 44.971 & 168.637 & 79.843 & 13.993 & 3265.971 \\
\hline $\mathbf{P}$ & 117.138 & 105.022 & 446.127 & 58.656 & 0.912 \\
\hline $\mathbf{S} * \boldsymbol{\theta}$ & 14.916 & 2.162 & 12.720 & 9.533 & 4.529 \\
\hline $\mathbf{S} * \mathbf{S p}$ & 6.387 & 2.148 & 5.892 & 2.333 & 7.882 \\
\hline $\mathbf{S} \mathbf{P}$ & 8.251 & 2.202 & 7.160 & 7.307 & 3.206 \\
\hline $\boldsymbol{\theta} * \mathbf{S p}$ & 31.968 & 5.528 & 1.996 & 4.428 & 13.265 \\
\hline $\boldsymbol{\theta} * \mathbf{P}$ & 9.542 & 4.178 & 4.530 & 4.470 & 7.132 \\
\hline $\mathbf{S p} * \mathbf{P}$ & 7.387 & 1.441 & 11.246 & 3.249 & 11.544 \\
\hline $\mathbf{S} * \boldsymbol{\theta} * \mathbf{S p}$ & 4.154 & 1.495 & 1.881 & 2.155 & 0.801 \\
\hline $\mathbf{S} * \boldsymbol{\theta} * \mathbf{P}$ & 3.503 & 1.763 & 3.429 & 1.397 & 1.353 \\
\hline $\mathbf{S} * \mathbf{S p} * \mathbf{P}$ & 2.244 & 1.156 & 3.832 & 3.213 & .140 \\
\hline $\boldsymbol{\theta} * \mathbf{S p} * \mathbf{P}$ & 4.782 & 2.133 & 7.062 & 5.595 & 10.088 \\
\hline $\mathbf{S} * \boldsymbol{\theta} * \mathbf{S p} * \mathbf{P}$ & 1.876 & 0.879 & 2.600 & 1.682 & 1.232 \\
\hline
\end{tabular}

Note: S: Seed, $\theta$ : Inclination of metering device, Sp: Speed, P: Number of cell 


\section{Degree of variation}

The coefficient of variation of spacing's is classified as singles. Lower the value of coefficient of variation in single's, better is the performance of a metering mechanism. It is evident from Figures 16,17 and 18 that the degree of variation increases with the increase in speed for all types of seed metering plates. The average degree of variation observed were at $S_{1}$ seed, 22.0, 25.0, 34.0 for 18 groove plate, $21.0,24.0,33.0$ for 24 groove plate and 20.0, 23.0, 32.0 for 30 groove plate at $\theta_{2}$ angle and forward speed 1.0, 2.0, $3.0 \mathrm{~km} / \mathrm{h}$ respectively. In $\mathrm{S}_{3}$ seed, 24.0, 29.0, 37.0 for 18 groove plate, 23.0, 28.0, 36.0 for 24 groove plate and 22.0, 27.0, 35.0 for 30 groove plate respectively.

\section{Seed damage}

The seed damage was estimated based on germination and visual damage and bruising. Bruising of pelleted seeds can be observed by visual observation of the samples used in the laboratory experiments on visual observation of the samples of $S_{1}, S_{2}$, and $S_{3}$ no prominent bruises were observed. There can be no damage to the seeds which are encapsulated within the outer coating in case of pelletized seeds.

\section{Selection of metering mechanism}

Final selection of metering system for radish planter based on the results of laboratory evaluation, with 24 groove seed metering plate with $45^{\circ}$ inclination angle and a forward speed of $2.0 \mathrm{~km} / \mathrm{h}$ was selected for the field evaluation. Missing index at $2.0 \mathrm{~km} / \mathrm{h}$ forward speed with 24 groove seed metering plate with $45^{\circ}$ inclination angle was $13.0 \%$ and multiple index was $12.0 \%$. The overall quality of feed index obtained with these parameters was $75.0 \%$ which is maximum when compared with other seed treatments, forward speeds and types of seed metering plate combinations with different angle of inclination of plates.

The inclination of metering device statistically influenced the average seed spacing and performance indices, followed by cell number, inclination angle, speed of operation and seed treatment. Highest feed index of $75.0 \%$ was obtained at plate inclination of $45^{\circ}$, with $2 \mathrm{~km} / \mathrm{h}$ speed of operation and 24 groove cell number when tested for $\mathrm{S}_{3}$ seed. Metering plate with 24 groove cells at $45^{\circ}$ inclination at $2 \mathrm{~km} / \mathrm{h}$ speed of metering device gave best performance with $\mathrm{S}_{3}$ seed, and thus recommended.

\section{References}

Ahmed, S., and Gupta, C. P. 1994. A manually operated electrostatic planter for small seeds. Agric. Mech. in Asia Afri. And Lat. Am., 25 (2), 29-34.

Anonymous, 1984. Sowing equipment-Test methods-Part I: Single seed drills (Precision drills). ISO: 7256/1, Geneva, Switzerland.

Anonymous, 1991. Agricultural Machinery Design and Data Handbook (Seeders and Planters). RNAM, Bangkok, Thailand.

Anonymous, 2015. http://www.Indiastat.com (Date of visit: 10th July, 2015).

Grewal, R. S., Khurana R., Manes G. S., Dixit A. and Verma A. 2015. Development and evaluation of tractor operated inclined plate metering device for onion seed planting, Agric Eng Int: CIGR, 17 (2), 31-38.

Kachman, S. D., and Smith J. A. 1995. Alternative measures of accuracy in plant spacing for planters using single seed metering. Trans ASAE 38:379-87.

Kowalczuk; Zarajczyk. 2006. Quality assessment of carrot seeding using precision belt seeder S011 Alex, 
Tekakom. Mot. Energy, 6, 41-45.

Otsuka, K., Kurota H. and Kobori O. 1986. Feasibility of precision planting by cell type metering devices. J. Jap. Soc. Agric. Machinery, 48(3-4), 361-367.

Shibata Y., Goto Y., and Tasaka K. 1990. Development of metering devices for small seeds. Bulletin of Chigoku
National Agricultural Experimental Station, 7, 37-46.

Zang, D., and Guo Y. 2009. Simulation design of the spiral groove precision seed-metering device for small grains. Comput. Comput. Technol. Agric., 293, $155-60$.

\section{How to cite this article:}

Anand Gautam, Rohinish Khurana, Gursahib Singh Manes, Anoop Dixit and Aseem Verma. 2017. Development and Evaluation of Inclined Plate Metering Mechanism for Radish (Raphanus sativus) Pelleted Seeds. Int.J.Curr.Microbiol.App.Sci. 6(10): 993-1003. doi: https://doi.org/10.20546/ijcmas.2017.610.120 